\title{
Regulation of Fatty Acid Transport Protein and Mitochondrial and Peroxisomal $\beta$-Oxidation Gene Expression by Fatty Acids in Developing Rats
}

\author{
FETTA OUALI, FATIMA DJOUADI, CLAUDIE MERLET-BÉNICHOU, BÉATRICE RIVEAU, \\ AND JEAN BASTIN
}

INSERM U319, Université Paris 7, Denis Diderot, 75251 Paris cedex 05, France

\begin{abstract}
ABST
Regulation of genes involved in fatty acid (FA) utilization in
heart and liver of weanling rats was investigated in response to
variations in dietary lipid content and to changes in intracellular
FA homeostasis induced by etomoxir, a blocker of FA import
into mitochondria. Northern-blot analyses were performed using
cDNA probes specific for FA transport protein, a cell membrane
FA transporter; long-chain- and medium-chain acyl-CoA dehy-
drogenases, which catalyze the first step of mitochondrial FA
$\beta$-oxidation; and acyl-CoA oxidase, a peroxisomal FA $\beta$-oxida-
tion marker. High-fat feeding from postnatal d 21 to 28 resulted
in a coordinate increase (58 to 136\%) in mRNA abundance of all
genes in heart. In liver, diet-induced changes in mitochondrial
and peroxisomal $\beta$-oxidation enzyme mRNAs (from 52 to $79 \%$ )
occurred with no change in FA transport protein gene expression.
In both tissues, the increases in mRNA levels went together with
parallel increases in enzyme activity. Changes in FA homeostasis
resulting from etomoxir administration led to a marked stimula-
tion (76 to 180\%) in cardiac expression of all genes together with
parallel increases in enzyme activities. In the liver, in contrast,
etomoxir stimulated the expression of acyl-CoA oxidase gene
\end{abstract}
Fatty acids are the main energy substrates supplied to developing mammals in maternal milk (1), and the importance of fatty acids in energy metabolism during this period is underscored by the severe clinical manifestations of inborn deficits in $\beta$-oxidation enzymes (2). Besides their role in energy metabolism, fatty acids might act as regulators of gene expression for enzymes and proteins involved in their own utilization, as consistently suggested by recent in vitro molecular data (3-6). In fact, fatty acids can bind and activate PPAR $\alpha$, a member of the steroid-thyroid hormone receptor superfamily (7), leading to transactivation of genes involved in the various fatty acid oxidation pathways (8). However, there are as yet little data regarding the physiologic relevance of these regulatory mechanisms.

Received July 29, 1999; accepted May 28, 2000.

Correspondence: Jean Bastin, INSERM U393, Hôpital Necker-Enfants Malades, 149 rue de Sèvres, 75743 Paris cedex 15, France. only. Feeding rats a low-fat diet containing $0.5 \%$ clofibrate, a ligand of peroxisome proliferator-activated receptor $\alpha$, resulted in similar inductions of $\beta$-oxidation enzyme genes in both tissues, whereas up-regulation of FA transport protein gene was restricted to heart. Altogether, these data suggest that changes in FA homeostasis in immature organs resulting either from highfat diet or $\beta$-oxidation blockade can efficiently be transduced to the level of gene expression, resulting in tissue-specific adaptations in various FA-using enzymes and proteins. (Pediatr Res 48: 691-696, 2000)
FATP, fatty acid transport protein
LCAD, long-chain acyl-CoA dehydrogenase
MCAD, medium-chain acyl-CoA dehydrogenase
ACO, acyl-CoA oxidase
$\operatorname{PPAR} \alpha$, peroxisome proliferator-activated receptor $\alpha$
CPT-1, carnitine palmitoyltransferase I
NEFA, nonesterified fatty acid

The objective of the present study was therefore to determine whether changes in whole body lipid balance performed in weanling rats could affect the expression levels of several genes encoding protein and enzymes involved in the transport and $\beta$-oxidation of fatty acids, in the immature heart and liver. FATP is an integral plasma membrane protein originally shown to increase cellular fatty acid uptake in adipocytes (9). The LCAD and MCAD genes encode enzymes that catalyze the initial step of mitochondrial fatty acid $\beta$-oxidation, with distinct carbon chain length specificities. Finally, the ACO gene, which encodes the first enzyme of peroxisomal fatty acid $\beta$-oxidation, is admitted to reflect the expression level of peroxisomal fatty acid catabolism (10).

We first sought to determine whether dietary manipulations of saturated medium- and long-chain fatty acids can induce variations in the expression levels of the genes studied. To further investigate in vivo gene regulation in response to fatty acids, we studied in parallel the effects on gene expression of 
Table 1. Body growth, food, energy, and lipid intakes and fatty acid plasma levels of animals fed a low-or high-fat diet during a 21- to 28-d period

\begin{tabular}{lccccc}
\hline \multicolumn{1}{c}{ Diet } & $\begin{array}{c}\text { Body growth } \\
(\mathrm{g} / \mathrm{d})\end{array}$ & $\begin{array}{c}\text { Food intake } \\
(\mathrm{g} / \mathrm{d})\end{array}$ & $\begin{array}{c}\text { Energy intake } \\
(\mathrm{kcal} / \mathrm{d})\end{array}$ & $\begin{array}{c}\text { Lipid intake } \\
(\mathrm{g} / \mathrm{d})\end{array}$ & $\begin{array}{c}\text { Fatty acid plasma levels } \\
(\mathrm{mM})\end{array}$ \\
\hline Low-fat & $5.5 \pm 1.7$ & $22.1 \pm 2.4$ & $49.0 \pm 5.4$ & $0.13 \pm 0.02$ & $0.27 \pm 0.04$ \\
High-fat & $3.2 \pm 0.5$ & $10.8 \pm 0.8^{* * *}$ & $44.0 \pm 3.3$ & $2.81 \pm 0.17^{* * *}$ & $0.54 \pm 0.04^{* * *}$ \\
High-fat + etomoxir & $2.9 \pm 0.4$ & $10.6 \pm 0.7^{* * *}$ & $43.0 \pm 2.6$ & $2.91 \pm 0.15^{* * *}$ & $0.48 \pm 0.08^{* *}$ \\
Low-fat + clofibrate & $4.7 \pm 1.0$ & $16.6 \pm 1.6^{*}$ & $37.0 \pm 3.6$ & $0.11 \pm 0.01$ & $0.07 \pm 0.02^{* *}$ \\
\hline
\end{tabular}

Values are mean \pm SEM of five animals. $* p<0.05 ; * * p<0.01$; *** $p<0.001$ compared with the low-fat group.

treating rats fed a high-fat diet with etomoxir, an inhibitor of mitochondrial CPT-1 (11), which induces intracellular build-up in long-chain fatty acids and fatty acid derivatives. Finally, mRNA studies were also performed in clofibratetreated rats.

The results obtained point out the ability of immature tissues to control gene expression of enzymes involved in various steps of cellular fatty acid metabolism as a function of fatty acid dietary intake and in response to changes in intracellular fatty acid homeostasis.

\section{METHODS}

\section{Animals and Diets}

Pregnant Wistar rats were bred and mated in our laboratory and had free access to water and standard food (UAR 113, containing, per $100 \mathrm{~g}, 51 \mathrm{~g}$ carbohydrate, $22 \mathrm{~g}$ protein, and $5 \mathrm{~g}$ lipid; UAR, Villemoisson-sur-Orge, France). Each litter was reduced to 10 animals at birth. Pups were kept with their mothers until d 21 after birth, and then weaned on various specific diets, from d 21 to 28 . All animal experiments were performed in accordance with the INSERM guidelines for the care and use of laboratory animals.

A group of animals was kept on a low-fat diet. This diet was obtained commercially from UAR and provided, per $100 \mathrm{~g}$, $58 \mathrm{~g}$ carbohydrate, $19 \mathrm{~g}$ protein, and $<1 \mathrm{~g}$ residual lipids; under this diet, lipids account for $<3 \%$ of the total caloric supply. A second group of animals was fed a high-fat diet, which was prepared by adding $25 \%$ coconut oil (Sigma Chemical Co., St. Louis, MO, U.S.A.) to the low-fat food, and provided, per $100 \mathrm{~g}, 41 \mathrm{~g}$ carbohydrate, $14 \mathrm{~g}$ protein, and $25 \mathrm{~g}$ lipid. Accordingly, lipids accounted for $55 \%$ of the caloric supply in the high-fat diet. For the metabolic inhibitor studies, the rats were fed the high-fat diet and received a daily i.p. injection of etomoxir ( $40 \mathrm{mg} / \mathrm{kg}$ body weight). Another group of rat pups was fed the low-fat diet supplemented with $0.5 \%$ (wt/wt) clofibrate, a PPAR $\alpha$ ligand (7). A final group of animals was kept on the low-fat diet and received a daily injection of glucagon ( $2 \mu \mathrm{g} / 100 \mathrm{~g}$ body weight) from $\mathrm{d} 21$ to 28 . Food intake in the various groups of animals was determined daily by weighing the amount of food consumed, and body weight measurements were performed in parallel.

On $\mathrm{d} 28$, the heart and liver were removed under ketamine anesthesia (100 mg/kg body weight; Imalgène, RhôneMérieux, Lyon, France). The tissues were immediately frozen in liquid nitrogen, and stored at $-80^{\circ} \mathrm{C}$. Blood samples were always collected at $0930 \mathrm{~h}$, from axillary artery, in heparinized glass tubes and immediately centrifuged. Plasma samples were kept at $-80^{\circ} \mathrm{C}$ until analysis. NEFA plasma levels were determined using the NEFA C WAKO kit (Dardilly, France).

\section{Northern Blot Analysis}

Total RNA was extracted in parallel from heart and liver in each animal. Electrophoresis through a formaldehydecontaining agarose gel ( $15 \mu \mathrm{g}$ of RNA/lane) and transfer to nylon membrane followed by UV cross-linking were performed as previously described (12). Each membrane included a selection of mRNA samples from heart or liver under all the experimental conditions tested. Importantly, the membranes corresponding to the two tissues were always probed in parallel and successively with the various cDNAs labeled with $\left[\alpha-{ }^{32} \mathrm{P}\right] \mathrm{dCTP}$ using the random primer technique. The mitochondrial enzyme cDNA probes used in this study were rat MCAD EcoRI fragment of $871 \mathrm{bp}(13)$ and rat LCAD EcoRI fragment of $1200 \mathrm{bp}$ (14). A 559-bp ACO cDNA (15) and a 717-bp cDNA comprising part of the D and $\mathrm{E}$ domains of the rat PPAR $\alpha$ (16) were obtained by reverse transcription coupled to PCR as described elsewhere (17). For FATP, the hybridization was performed with the $1.3-\mathrm{kb} B a m \mathrm{H} 1-B g l \mathrm{II}$ fragment of mouse cDNA (9).

Prehybridization and hybridization were performed in a hybridization oven at $68^{\circ} \mathrm{C}$, using the QuickHyb solution (Stratagene Europe, Netherlands) following the manufacturer's instructions. The membranes were washed twice with $2 \times \mathrm{SSC}$ $(1 \times \mathrm{SSC}$ is $0.15 \mathrm{M} \mathrm{NaCl}, 0.015 \mathrm{M}$ sodium citrate) for $10 \mathrm{~min}$ at room temperature, once with $2 \times \mathrm{SSC}$ and $1 \%$ SDS for 10 min at room temperature, and once with $1 \times \mathrm{SSC}$ and $1 \%$ SDS for 10 to $15 \mathrm{~min}$ at $60^{\circ} \mathrm{C}$. Signal density for each mRNA was quantified by computerized densitometric analysis of the autoradiograms. Finally and after the membrane were successively probed with the various cDNAs, the blots were hybridized with an 18-S cDNA probe to correct variations in the amount of RNA loaded.

\section{Measurement of Enzyme Activity}

LCAD and MCAD activity. $\mathrm{LCAD}$ and MCAD enzyme activities were determined spectrophotometrically at $37^{\circ} \mathrm{C}$ by following the decrease in ferricenium ion absorbance at 300 $\mathrm{nm}$ as previously described $(12,18)$. Briefly, tissue samples (30-70 mg) were weighed frozen, and the homogenates were immediately prepared as a $20 \%(\mathrm{wt} / \mathrm{vol})$ suspension in ice-cold $100 \mathrm{mM}$ HEPES, $\mathrm{pH}$ 7.6, and $0.1 \mathrm{mM}$ EDTA with a motordriven Teflon/glass homogenizer. The homogenates were then centrifuged. For enzyme assay, $5 \mu \mathrm{L}$ of supernatant was added to $500 \mu \mathrm{L}$ of reaction mixture containing $100 \mathrm{mM}$ HEPES, $\mathrm{pH}$ 


\section{Heart}

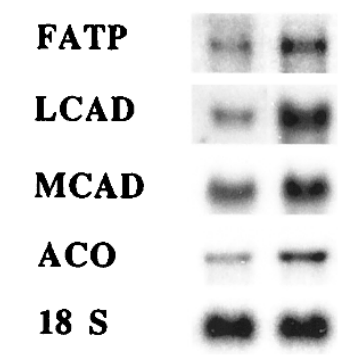

FATP

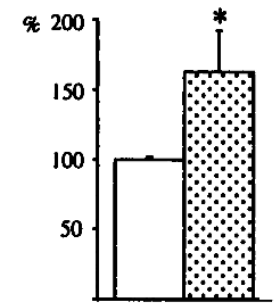

LCAD

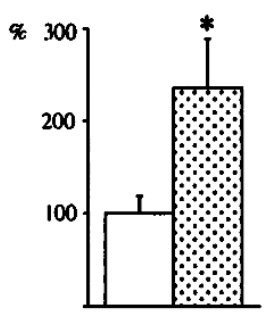

MCAD

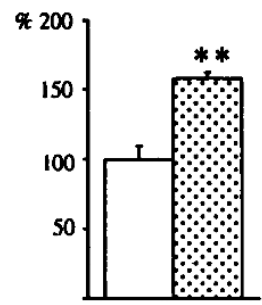

ACO

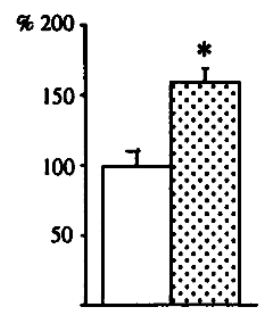

Liver
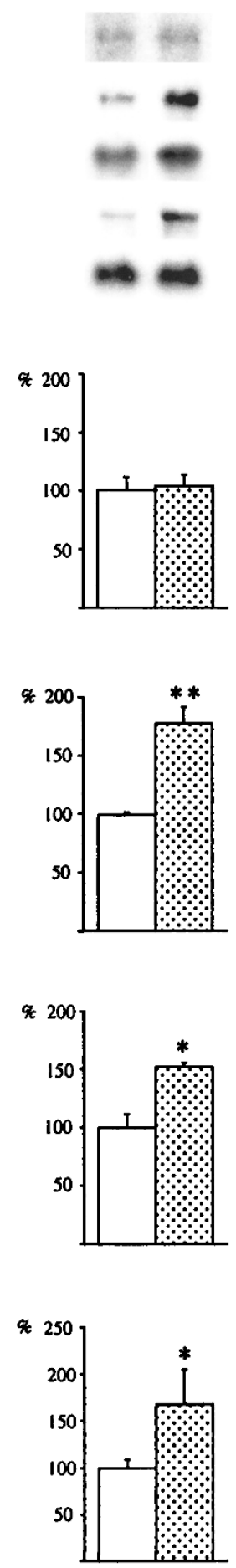

\section{low-fat high-fat}

Figure 1. Effects of dietary lipids on FATP, LCAD, MCAD, and ACO mRNA abundance in heart and liver of 28-d-old rats. Rats were fed either a low-fat or a high-fat diet from d 21 to 28 . Total RNA was isolated from the heart and liver of the same animal. Then, a blot was performed per tissue and successively hybridized with the various probes. The bars represent the mean \pm SEM of at least five animals. The values found in the low-fat group were taken as $100 \% . * p<0.05 ; * *<<0.01$ compared with the low-fat group.
7.6, $0.1 \mathrm{mM}$ EDTA, $200 \mu \mathrm{M}$ ferricenium hexafluorophosphate $\left(\mathrm{FcPF}_{6}\right)$, and $0.5 \mathrm{mM}$ sodium tetrathionate. The reaction mixture contained either $100 \mu \mathrm{M}$ palmitoyl-CoA or $100 \mu \mathrm{M}$ octanoyl-CoA for LCAD or MCAD determination, respectively. The enzyme activities were calculated from the decrease in $\mathrm{FcPF}_{6}$ absorbance observed during the first minute of reaction. The results were corrected for absorbance decrease measured in the absence of palmitoyl-CoA or octanoyl-CoA in the reaction mixture. The enzyme activities were expressed in micromoles of substrate oxidized per minute per gram wet weight.

Acyl-CoA oxidase activity. Acyl-CoA oxidase was determined fluorometrically by measurement of $\mathrm{H}_{2} \mathrm{O}_{2}$ production according to the method described by Vamecq (19), in which $\mathrm{H}_{2} \mathrm{O}_{2}$ reacts with homovanillic acid in the presence of peroxidase to give a fluorescent dimer. The assay medium, a total volume of $500 \mu \mathrm{L}$, contained $50 \mathrm{mM}$ glycylglycine buffer, $\mathrm{pH}$ 8.3, $200 \mu \mathrm{M}$ sodium azide $\left(\mathrm{NaN}_{3}\right), 0.55 \mathrm{mM}$ homovanillic acid, $3 \mu \mathrm{M}$ flavin adenine dinucleotide, $20 \mu \mathrm{M}$ lipid-free BSA, $20 \mu \mathrm{g} / \mathrm{mL}$ horseradish peroxidase type II, and $100 \mu \mathrm{M}$ palmitoyl-CoA. The reaction was started by addition of $5 \mu \mathrm{L}$ or $10 \mu \mathrm{L}$ of tissue homogenate, which was prepared in $3 \mathrm{mM}$ imidazole buffer, $\mathrm{pH} 7.0,0.25 \mathrm{M}$ sucrose, as described above. At $10 \mathrm{~min}$ of the reaction, aliquots of $50 \mu \mathrm{L}$ were taken and mixed with $1.5 \mathrm{~mL}$ of water, and the resulting fluorescence was read at an excitation wavelength of $315 \mathrm{~nm}$ and an emission wavelength of $420 \mathrm{~nm}$.

After correction for fluorescence of a blank incubated without substrate and calibration with a reference solution of $\mathrm{H}_{2} \mathrm{O}_{2}$, the fluorescence was converted into nanomoles of $\mathrm{H}_{2} \mathrm{O}_{2}$ produced per minute per gram wet weight.

\section{Expression of Results and Statistical Analysis}

mRNA abundance is expressed on a relative percentage basis. The data are expressed as mean \pm SEM. The means from five rats in each experimental group were subjected to one-way ANOVA and Fisher's exact test; $p<0.05$ was considered significant.

\section{RESULTS}

The values of growth, food and energy intake, lipid consumption, and NEFA plasma levels in the various groups of animals are presented in Table 1. Pups exhibited less appetite for high-fat than for low-fat food, as reflected by the food intake values. However, inasmuch as the caloric content per gram of high-fat food (4 kcal/g) was higher than that of low-fat food $(2.2 \mathrm{kcal} / \mathrm{g})$, the daily energy intakes were not significantly different under the various diets tested. Body growth rates appeared slightly lower under high-fat compared with low-fat diets; however, none of the differences in growth rates among the various groups reached statistical significance. Treatment by etomoxir did not result in changes in any of the variables measured, showing that etomoxir did not alter growth or nutritional status of the pups. As expected, treatment by clofibrate led to significantly lower circulating fatty acid levels. Altogether, feeding rats a high-fat diet resulted in a pronounced 
Table 2. Effect of dietary lipids on LCAD, MCAD, and ACO enzyme activities in heart and liver of 28-d-old-rats

\begin{tabular}{|c|c|c|c|c|c|c|}
\hline \multirow[b]{2}{*}{ Diet } & \multicolumn{3}{|c|}{ Heart } & \multicolumn{3}{|c|}{ Liver } \\
\hline & LCAD & MCAD & $\mathrm{ACO}$ & LCAD & MCAD & $\mathrm{ACO}$ \\
\hline Low-fat & $13.0 \pm 0.7$ & $10.9 \pm 0.5$ & ND & $9.4 \pm 0.5$ & $7.0 \pm 0.3$ & $234 \pm 56$ \\
\hline
\end{tabular}

LCAD enzyme activity is expressed in micromoles of palmitoyl-CoA oxidized per minute per gram wet weight.

MCAD enzyme activity is expressed in micromoles of octanoyl-CoA oxidized per minute per gram wet weight.

ACO enzyme activity is expressed in nanomoles of $\mathrm{H}_{2} \mathrm{O}_{2}$ produced per minute per gram wet weight.

Abbreviation: ND, not detectable.

Values are mean \pm SEM of 4 to 5 animals. ${ }^{*} p<0.05$; ${ }^{*} p<0.01 ; * * p<0.001$ compared with the low-fat group.

increase in dietary lipid intake and in fatty acid plasma levels, compared with low-fat fed rats.

Adaptive changes in gene expression and enzyme activity in response to a high-fat diet. Figure 1 shows that weanling rats fed on diets varying by their fat content resulted in significant changes in cardiac and hepatic gene expression patterns of fatty acid metabolism enzymes. In response to high-fat diet, FATP gene expression was increased (63\%) in the heart and was not affected in the liver. In contrast, heart and liver exhibited a coordinate up-regulation of all $\beta$-oxidation enzyme genes in response to a high-fat diet, the increases in mRNA levels ranging from $50 \%$ for MCAD to $136 \%$ for LCAD. The increases in mRNA levels paralleled increases in mitochondrial and peroxisomal enzyme activities in heart $(20 \%)$ and in liver (from 27 to $123 \%$ ) in response to high-fat diet (Table 2). ACO enzyme activity was undetectable in hearts of animals fed a low-fat diet and become measurable in rats fed a high-fat diet. To investigate a possible role of glucagon in mediating changes in gene expression in response to dietary factors, MCAD mRNA abundance was determined in rats fed a low-fat diet and receiving long-term treatment by glucagon for the d 21 to 28 period. As shown in Figure 2, cardiac and

\section{Heart}

\section{MCAD \\ $18 \mathrm{~S}$}

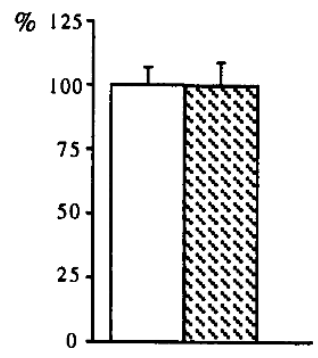

\section{Liver}
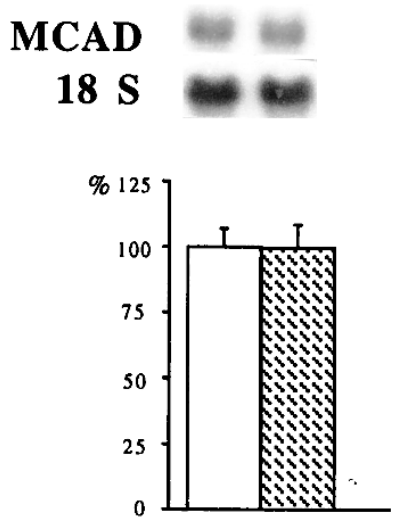

\section{vehicle glucagon}

Figure 2. Effects of glucagon on MCAD mRNA abundance in heart and liver of 28-d-old rats. Data were obtained from 28-d-old animals fed a low-fat diet from $\mathrm{d} 21$ to 28. During this period, rats received a daily injection of glucagon ( $2 \mu \mathrm{g} / 100 \mathrm{~g}$ body weight) or vehicle. Results are means \pm SEM of four rats.

\section{Heart}

Liver

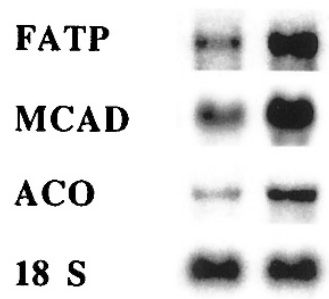

FATP
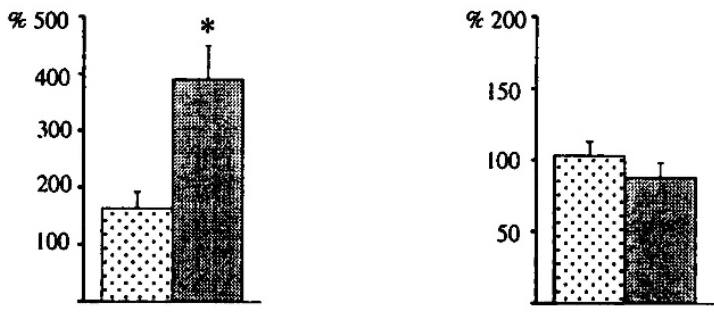

MCAD
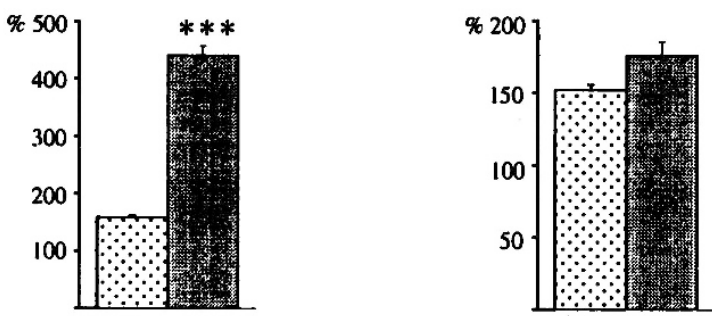

ACO
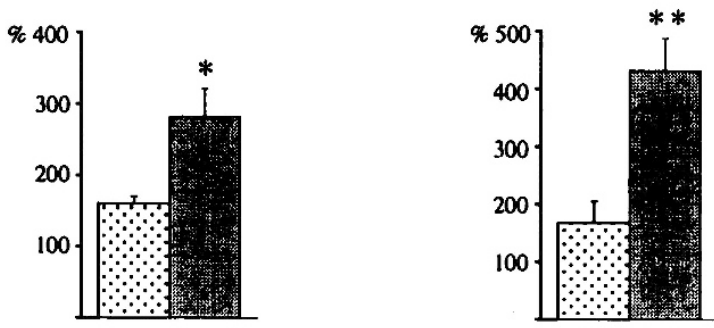

\section{3 high-fat 圈 high-fat + etomoxir}

Figure 3. Effects etomoxir on FATP, MCAD, and ACO mRNA abundance in heart and liver of 28-d-old rats. Rats were fed a high-fat diet from d 21 to 28. Some of these animals received, in addition, a daily i.p. injection of etomoxir (40 mg/kg body weight). Each group contains at least five animals. The bars represent the mean mRNA values \pm SEM. ${ }^{*} p<0.05 ;{ }^{*} p<0.01$; ${ }^{* * *} p<$ 0.001 compared with the high-fat group. 
Table 3. Effect of etomoxir on MCAD and ACO enzyme activities in heart and liver of 28-d-old-rats

\begin{tabular}{|c|c|c|c|c|}
\hline \multirow[b]{2}{*}{ Diet } & \multicolumn{2}{|c|}{ Heart } & \multicolumn{2}{|c|}{ Liver } \\
\hline & MCAD & $\mathrm{ACO}$ & MCAD & $\mathrm{ACO}$ \\
\hline High-fat & $13.2 \pm 0.6$ & $8.4 \pm 1.8$ & $8.9 \pm 0.4$ & $521 \pm 55$ \\
\hline
\end{tabular}

Enzyme activities are expressed as in Table 2.

Values are means \pm SEM of 4 to 5 animals.

$* * p<0.01 ; * * * p<0.001$ compared with the high-fat group.

hepatic MCAD mRNA steady-state levels were found to be unchanged in glucagon-treated pups, compared with vehicletreated rats.

Effects of etomoxir in rats fed a high-fat diet. The effects of etomoxir given to rats fed a high-fat diet on mitochondrial and peroxisomal $\beta$-oxidation gene expression are shown in Figure 3. Taking the values obtained in untreated rats fed a high-fat diet as reference, ACO mRNA levels were increased by $100 \%$ and $250 \%$ in heart and liver, respectively. The FATP gene expression was stimulated in heart but not in liver, as observed in response to high-fat feeding. Finally, MCAD gene expression was significantly raised in heart but not in liver. Changes in MCAD and ACO mRNA were accompanied by parallel increases in enzyme activities (Table 3).

Effects of clofibrate on heart and liver gene expression. The results obtained from heart and liver of rats weaned on low-fat food containing $0.5 \%$ clofibrate are presented in Figure 4. Clofibrate resulted in a general increase in heart mRNA levels of all genes, ranging from 2.3-fold for FATP, up to 3.5-fold in the case of LCAD. Liver LCAD, MCAD, and ACO genes were also markedly induced ( 3 to 7 times) in response to clofibrate. In contrast to heart, liver FATP gene expression was unaffected by clofibrate administration.

Effects of various treatments on PPARa gene expression. In both tissues, feeding rats high-fat, etomoxir- or clofibratecontaining diets did not significantly change PPAR $\alpha$ mRNA steady-state levels (Fig. 5).

\section{DISCUSSION}

Recent in vitro studies suggest that fatty acids might act as transcriptional regulators for a variety of genes encoding enzymes and proteins involved in lipid metabolism (3-6), but there are as yet little data to assess the significance of these regulatory mechanisms in vivo. The dietary manipulations performed in this study allowed us to induce large variations in the amount of saturated fat consumed by weanling rats for a 1-wk period. Our results demonstrate that the genes encoding FATP, LCAD, MCAD, and ACO are all putative targets for adaptive changes in response to dietary fat manipulations. The expressions of all genes were coordinately up-regulated in response to a high-fat diet in heart. In liver, high-fat feeding resulted in induced expression of all $\beta$-oxidation enzyme genes, but did not affect FATP mRNA levels. Changes in gene expression in rats fed a high-fat diet might result from hormonal factors and, in particular, from the rise in circulating glucagon, which results from the high lipid intake. However, long-term administration of glucagon to pups aged 21 to $28 \mathrm{~d}$ failed to induce changes in heart or liver MCAD gene expres-
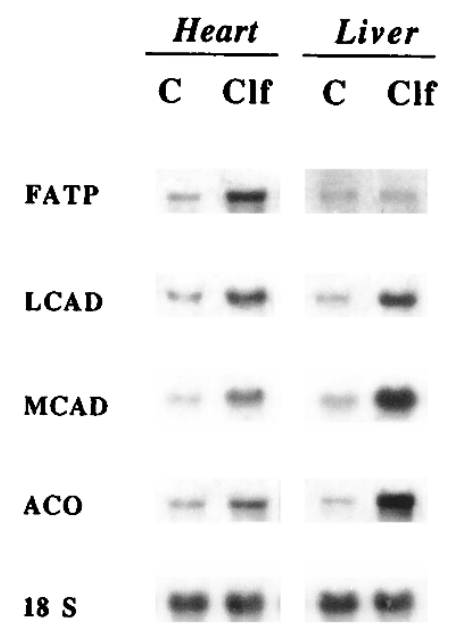

Figure 4. Effects of clofibrate on FATP, LCAD, MCAD, and ACO mRNA abundance in heart and liver of 28-d-old rats. Rats were fed either a low-fat diet or a low-fat diet containing $0.5 \%$ clofibrate from d 21 to 28 . The various RNA steady-state levels were compared by Northern blot analysis.

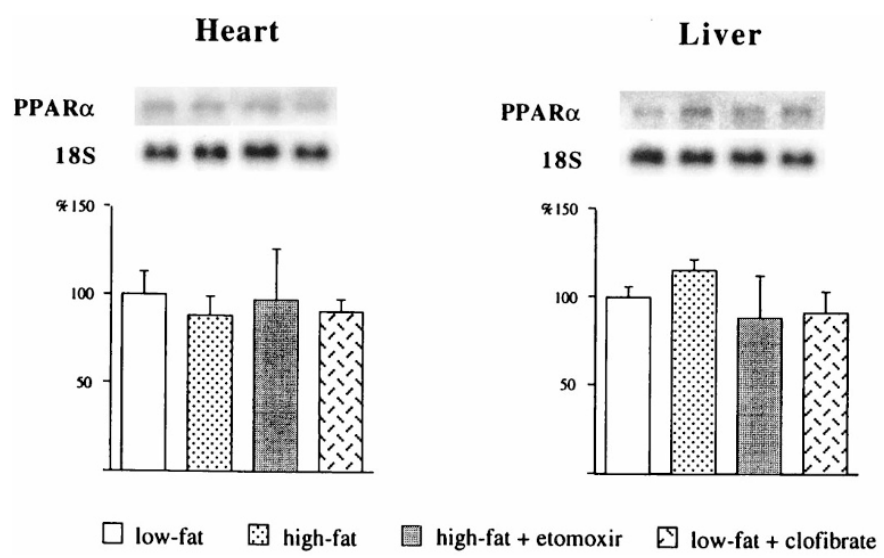

Figure 5. Effects of dietary lipids, etomoxir, and clofibrate on PPAR $\alpha$ mRNA abundance in heart and liver of 28-d-old rats. The blots used in the various previous studies were hybridized with $\operatorname{PPAR} \alpha$ probe as described in the "Methods" section.

sion, clearly suggesting that glucagon does not play a major role in mediating dietary-induced changes in gene expression observed in the present study.

Altogether, the mitochondrial and peroxisomal fatty acid $\beta$-oxidation pathways therefore appear as major targets for nutritional gene regulation in both tissues studied, whereas changes in dietary fat supply can also induce tissue-specific regulation of FATP gene expression.

These responses to a high-fat diet led us to investigate the gene expression patterns in immature tissues challenged by 
additional perturbations in lipid homeostasis. To address this question, we studied FATP, MCAD, and ACO mRNA levels in rats fed a high-fat diet and chronically treated by etomoxir. Inhibition by etomoxir of long-chain fatty acid import into the mitochondria leads to increased cellular levels of fatty acid and their derivatives, and therefore induces major changes in intracellular fatty acid homeostasis (11). Etomoxir administration resulted in a coordinate induction of all genes in heart with lower effects in liver. Previous results obtained from PPAR $\alpha$ knockout mice receiving etomoxir demonstrated that PPAR $\alpha$ plays a cardinal role in transducing changes in fatty acid homeostasis to the level of gene expression (20). Our data obtained from heart and liver of etomoxir-treated rats therefore suggest that $\operatorname{PPAR} \alpha$ could stimulate the expression of the genes studied in response to changes in intracellular fatty acid homeostasis. To evaluate the capacity of PPAR $\alpha$ to mediate changes in gene expression, we analyzed cardiac and hepatic mRNA levels in 1 rats fed a low-fat diet and receiving clofibrate, a PPAR $\alpha$ ligand. In fact, the four genes considered in this study were all found to be induced by clofibrate. It is noteworthy that FATP gene regulation in response to clofibrate was strictly restricted to heart, consistent with the results obtained from rats fed a high-fat fed diet or also treated with etomoxir. Studies run in adult rats already suggested that stimulation of FATP gene expression by peroxisome proliferators, could occur in a tissue-specific manner (21). Both developing heart and liver expressed significant levels of PPAR $\alpha$ mRNA, and none of the treatments performed in this study led to changes in the steady-state levels of PPAR $\alpha$.

Altogether, the present in vivo results indicate that the $\operatorname{PPAR} \alpha$ gene regulation pathway is active in the immature heart and liver of weanling rats. These results also demonstrate that fatty acids can exert an in vivo autoregulatory and coordinate effect over gene expression, which can target not only peroxisomal or mitochondrial $\beta$-oxidation enzymes but also a protein involved in fatty acid transport.

The authors thank Drs. A. Strauss and D.P. Kelly for providing us with the rat LCAD and MCAD cDNAs, respectively. We also thank Dr. J.E. Schaffer for the gift of the mouse FATP cDNA.

\section{REFERENCES}

1. Girard J, Ferré P, Pégorier JP, Duée PH 1992 Adaptation of glucose and fatty acid metabolism during perinatal period and suckling-weaning transition. Physiol Rev 72:507-562
2. Vockley J 1994 The changing face of disorders of fatty acid oxidation. Mayo Clin Proc 69:249-257

3. Assimacopoulos-Jeannet F, Thumelin S, Roche E, Esser V, McGarry JD, Prentki M 1997 Fatty acids rapidly induce the carnitine palmitoyltransferase I gene in the pancreatic B-cell line INS-1. J Biol Chem 272:1659-1664

4. Berthou L, Saladin R, Yaqoob P, Branellec D, Calder P, Fruchart JC, Denèfle P, Auwerx J, Staels B 1995 Regulation of rat liver apolipoprotein A-I, apolipoprotein A-II and acyl-coenzyme A oxidase gene expression by fibrates and dietary fatty acids. Eur J Biochem 232:179-187

5. Chatelain F, Kohl C, Esser V, Mc Garry JD, Girard J, Pegorier JP 1996 Cyclic AMP and fatty acids increase carnitine palmitoyltransferase I gene transcription in cultured rat hepatocytes. Eur J Biochem 235:789-798

6. Gulick T, Cresci S, Caira T, Moore DD, Kelly DP 1994 The peroxisome proliferatoractivated receptor regulates mitochondrial fatty acid oxidative enzyme gene expression. J Biol Chem 91:11012-11016

7. Forman BC, Chen J, Evans RM 1997 Hypolipidemic drugs, polyunsaturated fatty acids and eicosanoids are ligands for PPAR $\alpha$ and $\delta$. Proc Natl Acad Sci USA 94:4312-4317

8. Lemberger T, Desvergne B, Wahli W 1996 Peroxisome proliferator-activated receptors: a nuclear receptor signaling pathway in lipid physiology. Annu Rev Cell Dev Biol 12:335-363

9. Schaffer JE, Lodish HF 1994 Expression cloning and characterization of a novel adipocyte long chain fatty acid transport protein. Cell 79:427-436

10. Kunau WH, Dommes V, Schulz H $1995 \beta$-oxidation of fatty acids in mitochondria, peroxisomes, and bacteria: a century of continued progress. Prog Lipid Res 34:267342

11. Declercq PE, Falck JR, Kuwajima M, Tyminski H, Foster DW, McGarry JD 1987 Characterization of the mitochondrial carnitine palmitoyltransferase enzyme system: 1. Use of inhibitors. J Biol Chem 262:9812-9821

12. Djouadi F, Riveau B, Merlet-Bénichou C, Bastin J 1997 Tissue-specific regulation of medium chain acylCoA dehydrogenase gene by thyroid hormones in the developing rat. Biochem J 324:289-294

13. Kelly DP, Kim JJ, Billadello JJ, Hainline BE, Chu TW, Strauss AW 1987 Nucleotide sequence of medium-chain acyl-CoA dehydrogenase mRNA and its expression in enzyme-deficient human tissue. Proc Natl Acad Sci USA 84:40684072

14. Hainline BE, Kahlenbeck DJ, Grant J, Strauss AW 1993 Tissue specific and developmental expression of rat long- and medium-chain acyl-CoA dehydrogenases. Biochim Biophys Acta 1216:460-468

15. Miyazawa S, Hayashi H, Hijikata M, Ishii N, Furuta S, Kagamiyama H, Osumi T, Hashimoto T 1987 Complete nucleotide sequence of cDNA and predicted amino acid sequence of rat acyl-CoA oxidase. J Biol Chem 262:8131-8137

16. Lemberger T, Saladin R, Vasquez M, Assimacopoulos F, Staels B, Desvergne B, Wahli W, Auwerx J 1996 Expression of the PPAR $\alpha$ gene is stimulated by stress and follows a diurnal rhythm. J Biol Chem 271:1764-1769

17. Ouali F, Djouadi F, Merlet-Benichou C, Bastin J 1998 Dietary lipids regulate $\beta$-oxidation enzyme gene expression in the developing rat kidney. Am J Physiol 275:F777-F784

18. Djouadi F, Bastin J, Kelly DP, Merlet-Benichou C 1996 Transcriptional regulation of mitochondrial oxidative genes in the developing rat kidney by glucocorticoids. Biochem J 315:555-562

19. Vamecq J 1990 Fluorometric assay of peroxisomal oxidases. Anal Biochem 186:340 349

20. Djouadi F, Weinheimer CJ, Saffitz JE, Pitchford C, Bastin J, Gonzalez FJ, Kelly DP 1998 A gender-related defect in lipid metabolism and glucose homeostasis in peroxisome proliferator-activated receptor $\alpha$-deficient mice. J Clin Invest 102:10831091

21. Martin G, Schoonjans K, Lefebvre AM, Staels B, and Auwerx J 1997 Coordinate regulation of the expression of the fatty acid transport protein and acyl-CoA synthetase genes by PPAR $\alpha$ and PPAR $\gamma$ activators. J Biol Chem 272:2821028217 